\title{
The massive production of iron in the Sahelian belt: Archaeological investigations at Korsimoro (Sanmatenga - Burkina Faso)
}

\author{
Vincent Serneels \\ Department of Geosciences, University of Fribourg, Fribourg, Switzerland
}

\begin{abstract}
The large smelting site of Korsimoro was investigated during two fieldwork campaigns in 2011 and 2012. Four different technical traditions are identified. Each is characterized by the spatial organization of the working area, the architecture of the furnace, and the assemblages of wastes. Each technical tradition corresponds to one chronological phase. Phase KRS 1 lasted between 600 and 1000 AD and is characterized by small-scale production. Phases KRS 2 and 3, between 1000 and 1450 AD, showed a very significant increase of the production with an important impact on the organization of the society. There is a collapse of the industry at the time of the installation of the Nakomse conquerors followed by a recovery of the production at a small scale during the 17 th century.
\end{abstract}

\section{KEYWORDS}

Africa; archaeology;

bloomery; Burkina Faso; iron; precolonial; quantification;

smelting; technology

\section{Introduction}

Burkina Faso has a long-lasting tradition of ethnological and archaeological research on precolonial iron production. Ancient native populations of blacksmiths are already mentioned in the traditional oral history of the old Kingdoms of the Moogo, referring to the 15th and 16th centuries [1-3]. Early records on iron smelting were produced by European travelers and colonial administrators in the late 19th and early 20th centuries [4-6]. During the 1970s, a major work, under the leadership of Prof. J.-B. Kiethéga, was undertaken to record the oral traditions and to locate and describe the material remains [7-9]. Academic research is still ongoing at the universities of Ouagadougou and Koudougou [10].

Recently, in the frame of the joint project (Fribourg, Ouagadougou, Abidjan), an extended smelting site has been investigated at Korsimoro during two fieldwork campaigns of 4 weeks (2011 and 2012). The project aimed to produce new scientific data on iron production in Western Africa and to train young African archaeologists in basic archaeometallurgical fieldwork. The main scientific results are published in two preliminary reports $[11,12]$.

The town of Korsimoro is located $70 \mathrm{~km}$ to the North-East of Ouagadougou, close to the town of Kaya (Sanmatenga Province, Burkina Faso, $12^{\circ} 49^{\prime} 11.68^{\prime \prime} /-001^{\circ} 64^{\prime} 27.84^{\prime \prime}$, Fig. 1). It is surrounded by a typical Sahelian landscape of savannah with few trees (Fig. 2). The topography is almost flat with low hills to the North. The remains related to iron smelting form a dozen of concentrations, extending SW/NE for $10 \mathrm{~km}$ along the watercourse of a temporary tributary of the Nakambé, the former White Volta (Fig. 3). All together, the total mass of slag is estimated up to 60,000 tons after detailed field survey. Hundreds of furnace ruins can be seen (Fig. 4). Most of the visible remains are related to iron ore smelting and evidence for mining or smithing are limited. To the North, a few kilometers away, the Birimian volcano-sedimentary rocks form a range of low hills. The laterite formed on top of those rocks is probably a good ore; however, this area has not yet been investigated in detail and the location of the mining sites is still unknown. Long-lasting human occupation can be inferred from the numerous places with scattered potsherds. One large ancient funerary site has been spotted during fieldwork.

\section{Material and Methods}

\section{Investigation strategy}

The focus was the metallurgical aspects. During preliminary survey, four main types of smelting remains were identified, grouping more than $95 \%$ of the features.

In-depth investigations were implemented on the four major groups, including the topographic mapping of typical areas, the excavations of well-preserved furnaces, and test pits for the quantification of the waste assemblages and the stratigraphic sampling of charcoal for dating. The extended survey, based on the high-quality satellite images, the field walking, and the GPS positioning, allows the mapping of most of the areas of interest and the allocation of each feature to a specific group.

Later on, 19 samples, mainly of wood charcoal but also of carbonized straw, when available, were dated by radiocarbon method (Beta Analytic) [11, 12]. Archaeomagnetic data were obtained from several furnaces [13]. The preliminary archaeometallurgical investigations on slag and related materials were performed at the University of Fribourg (geochemistry by XRF, mineralogy by XRD, and optical and electronic microscopy on thin polished sections [14]). The

CONTACT Vincent Serneels Vincent.serneels@unifr.ch Department of Geosciences, University of Fribourg, Chemin du Musée 6, CH-1700 Fribourg, Switzerland. 


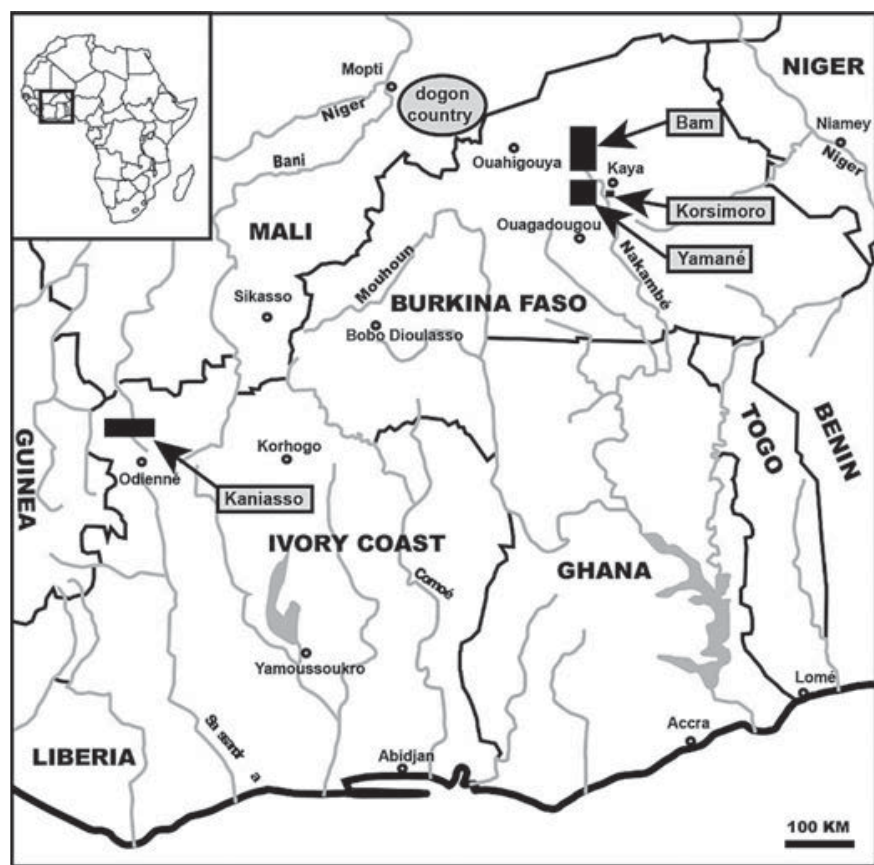

Figure 1. Map of West Africa with the locations of Korsimoro and of other areas with recent research on ancient iron production discussed in the text.

anthracological identification of the wood species used as fuel is ongoing [15].

The results of the survey, excavations, and laboratory studies are the characterization of the four main technical traditions, the estimates of the quantities of smelting slag for each group at the level of the all site and the reconstruction of a chronologic frame for the iron production at Korsimoro.

Technical traditions are characterized at three different levels with intrinsic criteria.

1. The general spatial organization of the working area is described: shape and dimensions of the waste discharge areas, relative positions of the furnaces, and the other features when present (ore storage, etc.).

2. The furnaces are characterized: architecture below and above ground, evidence for air supply, building techniques, and materials.

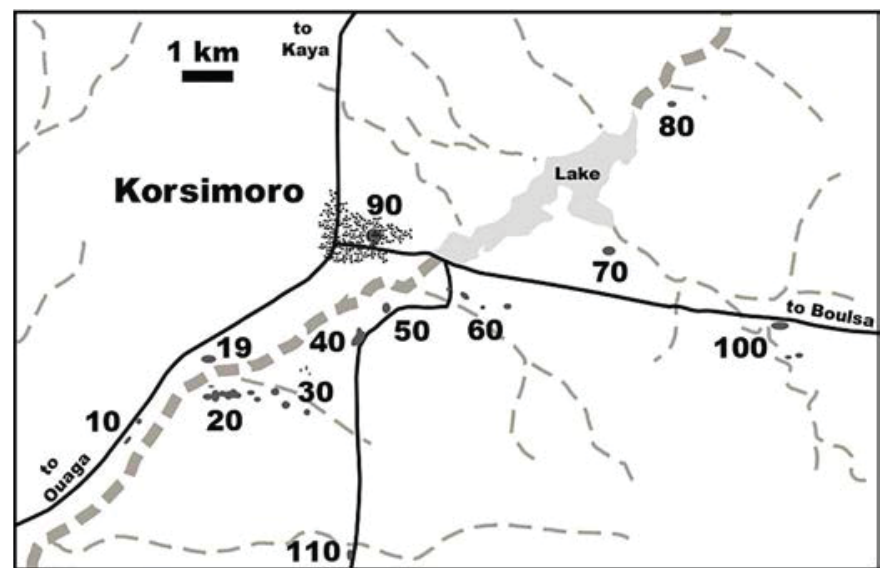

Figure 3. Map of the iron production complex of Korsimoro. Numbers refer to area with accumulations of smelting remains (Zones).

3. The waste assemblages are defined: full descriptions (shape, aspect, dimensions, composition) of slag types, tuyères, and other materials. The proportions between the different wastes are measured from the excavated test pits $(0.25$ to $0.5 \mathrm{~m}^{3}$ ).

These criteria allow the comparisons with the known archaeological finds apart from Korsimoro. The extrinsic criteria, like dating, spatial distribution, and quantification, attached to each tradition, provide the most important elements to reconstruct the history of the iron production.

All criteria refer directly to the archaeological remains, studied on the field or in the laboratory. They provide an efficient frame for a classification of the smelting techniques as applied elsewhere [16-18]. At Korsimoro the remains are quite well preserved, so many observations are of good quality, but some points remain always uncertain. For example, no furnace is fully preserved and the height of the shaft cannot be measured directly, so this is always an estimate.

Spatial and stratigraphic relations, together with the 19 radiocarbon dates and the related archaeomagnetic measurements, allow to build up a chronological frame for the iron production activity at Korsimoro. Each of the technical tradition corresponds to one single chronological phase and relative durations can be estimated (Fig. 7) [12].

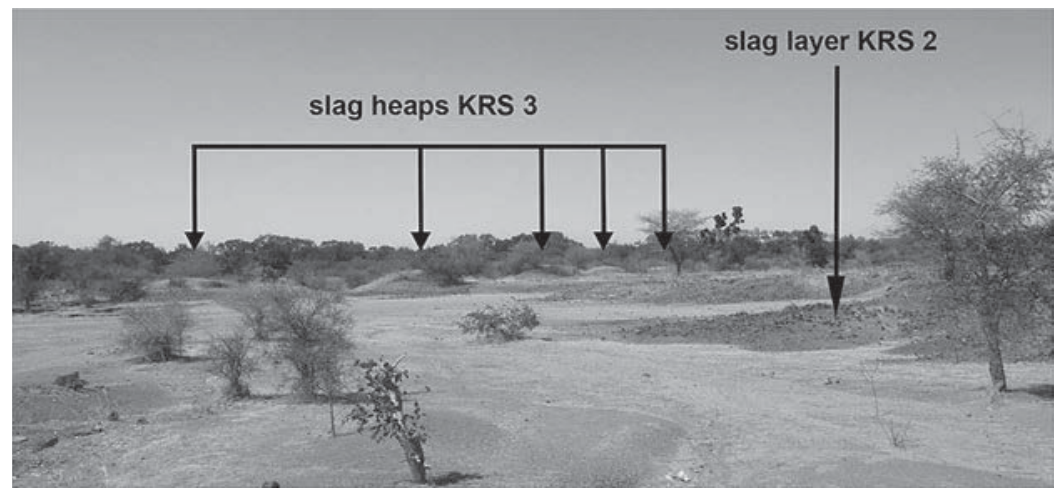

Figure 2. Typical landscape of the smelting site of Korsimoro (north eastern part of the zone 20). The five heaps covered with grass correspond to typical annular workshops of the technical tradition KRS $3(13$ th-14th c. AD). On the right, the bank of the fluviatil terrace is covered with slag fragments from the layer of wastes related to technical tradition KRS 2 (11th-13th c. AD). 

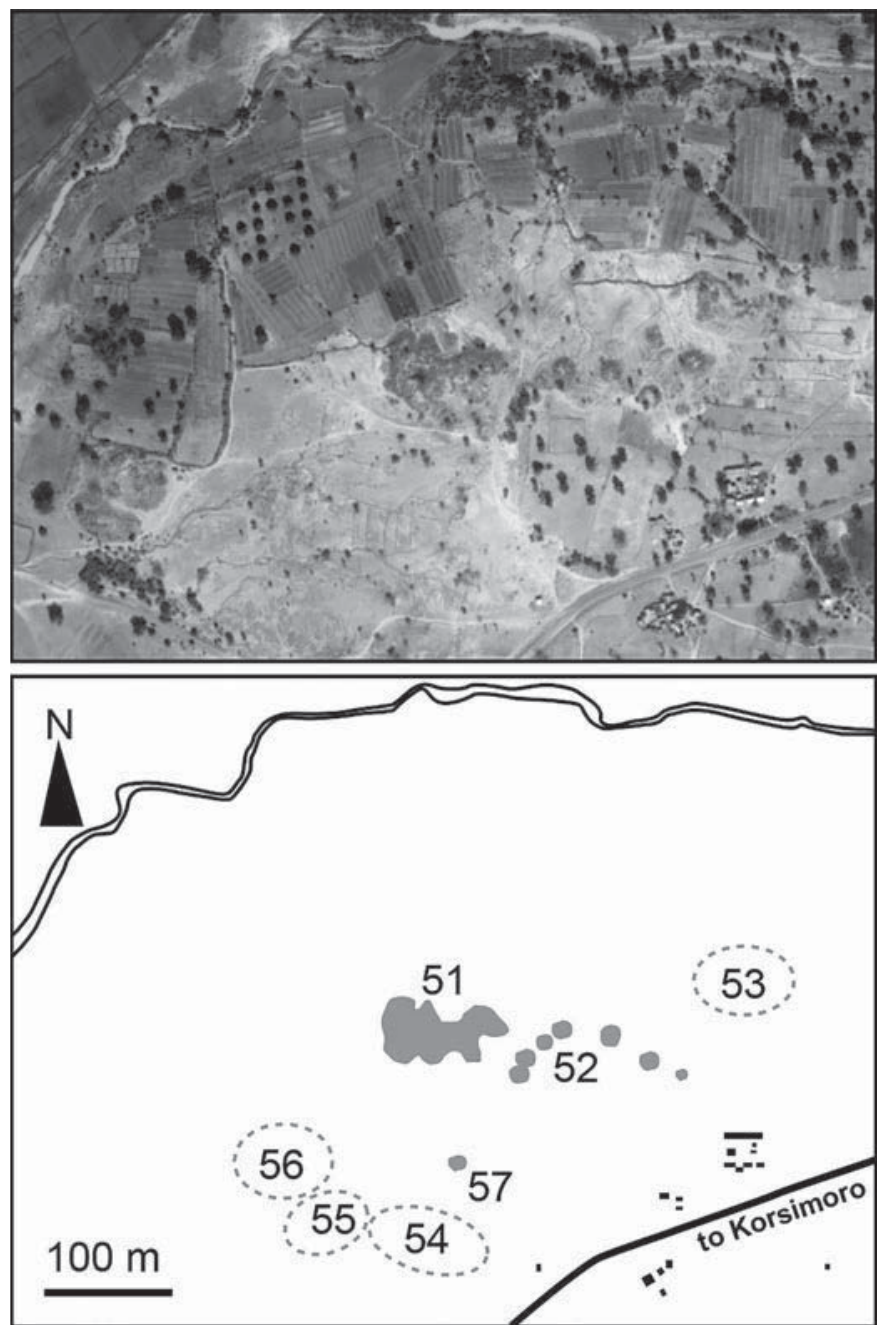

Figure 4. Satellite view of the Zone 50 of the smelting complex of Korsimoro. Sector 51 is an extended slag layer $\left(100 \times 50 \mathrm{~m}, 3850 \mathrm{~m}^{2}\right.$, about $1500 \mathrm{t}$ slag) with 30 bases of furnace typical for the technical tradition KRS 2. In sector 52, there are 7 annular slag heaps (20-30 m diameter, $1750 \mathrm{~m}^{2}, 335 \mathrm{t}$ slag), each with a central furnace, typical for the technical tradition 3. One additional heap of this type is located in sector 57. In sector 53, there are 145 large bases of furnace related to the technical tradition KRS 1 ( 5 to $15 \mathrm{t}$ slag). Similar furnaces are also present in sectors 55 and 56 (estimated up to 200 furnaces). In sector 54, there are 251 very small bases of furnace related to the technical tradition KRS 4 (10-15 t slag).

It must be kept in mind that this approach, based on the material remains only, is far from giving a full description of all aspects of the complete production line of iron, from the ore to the finished objects. Many important technical steps are not taken into account (mining, ore dressing, smithing, etc.). Furthermore, cognitive, social, and ritual aspects of the iron production line are almost completely ignored. For example, the absence of archaeological evidence for rituals associated with the iron smelting practices at Korsimoro is no proof of the absence of those rituals. Moreover, there is no reason to underestimate the importance of those "archaeologically invisible" aspects in the definition of a technical tradition.

Systematic and more detailed discussion of the criteria used for classification is given in the first report on Korsimoro [11]. In the following section, only the main specific features of each technical tradition are presented.

\section{Discussion}

\section{The four technical traditions of iron smelting recorded at Korsimoro}

\section{Technical tradition KRS 1: Large furnace with slag pit and single use: 7th-10th century $A D$}

The typical remains related to KRS 1 are furnace bases arranged in linear batteries of 5-15 units forming larger clusters. Each base is a medium size (internal diameter: $80 \mathrm{~cm}$ ) circular pit excavated in the ground (depth: $40 \mathrm{~cm}$ ) (Fig. 5a, b and Fig. 6a). The upper part of the pit is coated with clay. The pit is filled with slag pieces and sediment. The amount of slag is highly variable from one smelt to another, ranging from 10 to $200 \mathrm{~kg}$. A layer of burnt straw has been found at the base of the filling.

The organization in batteries of single furnaces is interpreted as the result of one campaign of iron smelting, possibly repeated on a seasonal basis by a specific group of individuals. The absence of slag heaps is explained by the abandonment of the slag inside the pit after a single use. On the contrary, organized deposits of about ten tuyères at the end of a battery indicate the use of the tuyères for several smelts in a campaign. At the ground level, the horizontal upper surface of the clay wall is accurately smoothed. This is not the effect of an erosional leveling but the result of the building process. This surface supported the ten tuyères arranged radially. Only scattered fragments of furnace wall were found, while a much higher quantity would have been expected, if a full shaft was built on top of each pit. It is then tempting to assume that a single mobile shaft was used during one smelting campaign. The mobile shaft is simply put on the tuyères and the gaps filled with earth. A similar situation has been documented by ethnographic research in Niger [19, 20]. No similar furnace is described in the ethnographic record for the Burkina Faso [7]. From the archaeological point of view, this type of furnace has not been described except in a recent survey in the neighboring areas of Yamané [15] and Bam [10]. This is probably the reflection of the state of the knowledge more than that of the archaeological reality.

\section{Technical tradition KRS 2: Very large furnace with slag pit and multiple use: 11th-13th century $A D$}

The technical tradition KRS 2 is characterized by extended layers of slag fragments of moderate thickness $(0.50-1.5 \mathrm{~m})$. Furnace remains are protruding without clear organization at distances of a few meters or tens of meters. The furnaces are quite large (internal diameter: $100 \mathrm{~cm}$ ) and massive. At the bottom, a bowl is excavated below ground (depth: $60 \mathrm{~cm}$ ) (Fig. 5c, d and Fig. 6b). There are four large openings at the ground level supporting a shaft built with clods of clay mixed with straw (so-called "banco"). The shaft must have been at least $2 \mathrm{~m}$ high above ground.

Some of the furnaces were still containing a very large block of slag filling entirely the underground bowl (200-500 kg). Those blocks contain recycled fragments of tuyères placed inside the furnace before the smelt and later entrapped in the slag (Fig. 5d). The reason for this arrangement is not clear but one can imagine that the reused tuyère fragments prevent the drop of the bloom below the level of the air blast. It is also probable 

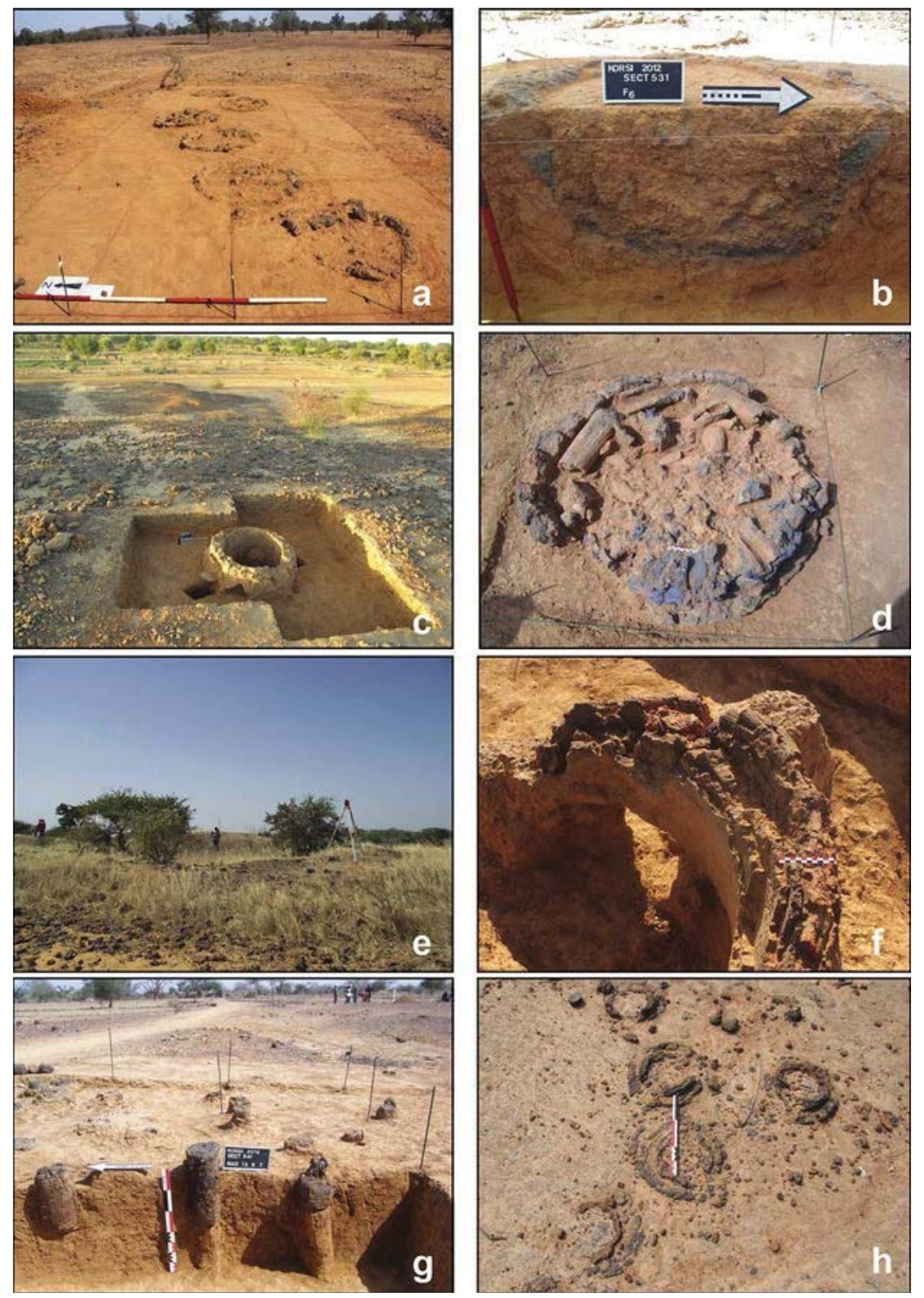

Figure 5. Typical archaeological remains for the four different smelting traditions at Korsimoro: (a) Technical tradition KRS 1 (7th-10th c. AD): Battery of 6 large furnaces $(80 \mathrm{~cm}$ diameter). Only the lower part excavated in the ground is preserved. Zone 100, Sector 1050. (b) Technical tradition KRS 1 (7th-10th c. AD): Section of one base of furnace with the clay lining in the upper part and a layer of carbonized straw at the base. The filling contains about $40 \mathrm{~kg}$ of slag. Zone 50 , Sector 53 , Furnace 6. (c) Technical tradition KRS 2 (11th-13th c. AD): General view of one excavated furnace. The shaft is preserved about $1 \mathrm{~m}$ above the original level of circulation and must have been at least $2 \mathrm{~m}$ high. Zone 50, Sector 51, Furnace 1. (d) Technical tradition KRS 2 (11th-13th c. AD): Big block of slag (1 m diameter) containing embedded reused pieces of tuyère. (e) Technical tradition KRS 3 (14th-15th c. AD): Annular slag heap with a $2 \mathrm{~m}$ high bump on the West (behind the student). Zone 20, Sector 223, Heap 3. (f) Technical tradition KRS 3 (14th-15th c. AD): Furnace wall. The central part is made with fragments of tuyère. There are three layers of clay lining on the inner surface (repairs) and two on the outer surface. Zone 20, Sector 29, Furnace 2. (g) Technical tradition KRS 4 (17th c. AD): Battery of 12 very small furnaces $(20 \mathrm{~cm}$ diameter). The trench shows three slag blocks of different sizes for the same type of furnace. Zone 50 , Sector 54 , Battery 541 . (h) Technical tradition KRS 4 (17th c. AD): Battery of very small furnaces $(20 \mathrm{~cm}$ diameter). Unexcavated. Zone 20, Sector 227.

that the presence of the tuyère fragments in the slag helped to break the block after the smelt. The extended layers of slag fragments demonstrate clearly the multiple use of each furnace.

This type of furnace can be incorporated in the large group of the "boanga" described by Prof. J.-B. Kiethéga [7]. Inside this large family, detailed descriptions of the remains are required to make accurate comparisons. The actual knowledge is too limited to proceed further.

\section{Technical tradition KRS 3: Large furnace with tapped slag and multiple use: 14th-15th century $A D$}

The slag heaps of the technical tradition KRS 3 have a typical annular shape with one or two entrances to the East and a heap of waste to the West. The furnace is in the center of the ring. It is a large construction (internal diameter: $100 \mathrm{~cm}$ or more), built with recycled fragments of tuyères linked with clay (Fig. 5e, f and Fig. 6c). There is no significant digging below the ground and five openings are left at the base of the shaft. The one facing East is larger and seems to be the door for tapping slag. On the opposite side, a wall made of large slag fragments facilitated the loading of the ore and fuel.

The western heap is exclusively made of small pieces of tapped slag while the rest of the ring contains various debris: tapped slag, internal slag block with tuyère fragments embedded in, and fragments of tuyères and furnace wall. The amount of slag per smelt can be estimated to $200-300 \mathrm{~kg}$. 
KRS 1 Induced draft

Slag pit

Single use

KRS 2

Induced draft

Slag pit

Multiple use

KRS 3

Induced draft

Slag tapping

Multiple use

KRS 4

Bellows

Slag pit

Single use
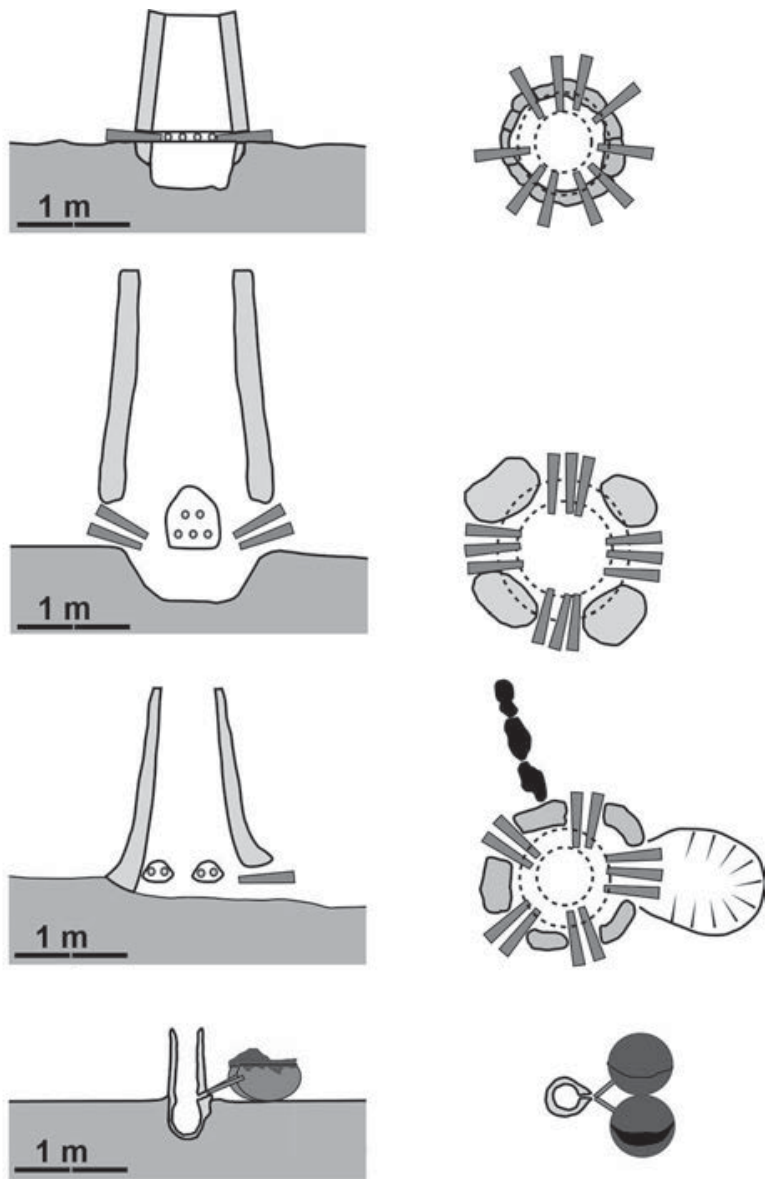

Figure 6. Schematic reconstructions of the furnaces of the four different smelting traditions at Korsimoro (plan and section): (a) Technical tradition KRS 1 (7th-10th c. AD). (b) Technical tradition KRS 2 (11th-13th c. AD). (c) Technical tradition KRS 3 (14th-15th c. AD). (d) Technical tradition KRS 4 (17th c. AD).

This type of furnace can also be incorporated in the large group of the "boanga" described by Prof. J.-B. Kiethéga [7]. The free standing furnaces of the site of Tiwèga near Kaya seem to share significant features with the KRS 3 technical tradition. Very similar furnaces have been excavated in the North of Ivory Coast, near Kaniasso (tradition KAN 1) $[21,22]$.

Technical tradition KRS 4: Very small furnace with slag pit and single use: 17 th century $A D$

The furnaces of the technical tradition KRS 4 are organized in batteries of 10-50 units forming larger clusters. The furnaces are very small (internal diameter: $20 \mathrm{~cm}$ ). No trace of the structure above ground is preserved. The lower part of the furnace is a cylindrical pit (depth: $35 \mathrm{~cm}$ ), lined with clay and filled with one single block of slag weighing 10 to $50 \mathrm{~kg}$ (Fig. 5g, h and Fig. 6d). The upper surface of the burnt lining is irregular, probably indicating an erosional leveling. No clay tuyère was found associated with this type of furnace.

The spatial organization speaks for repetitive campaigns of iron smelting. The very small size of the furnace is an argument in favor of the use of bellows and not of induced draft. By comparison to techniques KRS 2 and 3, the slag blocks of KRS 4 contain a much higher proportion of iron, present as wüstite or even metallic iron, indicating a less efficient process.
Very similar archaeological features were investigated in other parts of Burkina Faso. They are identified on other sites near Korsimoro (Tiwega near Kaya and in the area of Yamané: [15], see also "fonoga" of Kiethéga [7]), in the provinces of Bulkiendé [8] and of Bam [10]. Similar furnaces are mentioned in Northern Benin [23] and near Niamey in Niger [24] but also to the West in the Sénégal valley [25].

\section{Technical variability}

The four techniques present at Korsimoro can be distinguished on the basis of significant differences. The techniques KRS 1, 2, and 3 seem to have used natural draft. This assumption is based on the large number of tuyères and the important size of the shafts. On the contrary, technique KRS 4 , without clay tuyère and with a very small shaft, cannot work with natural draft. In this case the use of bellows is hypothesized. The techniques KRS 1 and KRS 4 are based on furnaces with single use, while the furnaces of techniques KRS 2 and 3 were used many times and repaired. They were probably used for decades. The furnaces of techniques KRS 1, 2, and 4 are designed to produce exclusively internal slag while the KRS 3 furnaces deliver mainly tapped slag. Technique KRS 4 shows a lower efficiency and a higher loss of iron.

There are also similarities or shared practices. One good example is the use of recycled tuyère fragments to fill the lower part of the furnace of KRS 2 and 3. The spatial organization of KRS 1 and KRS 4 is very similar. 


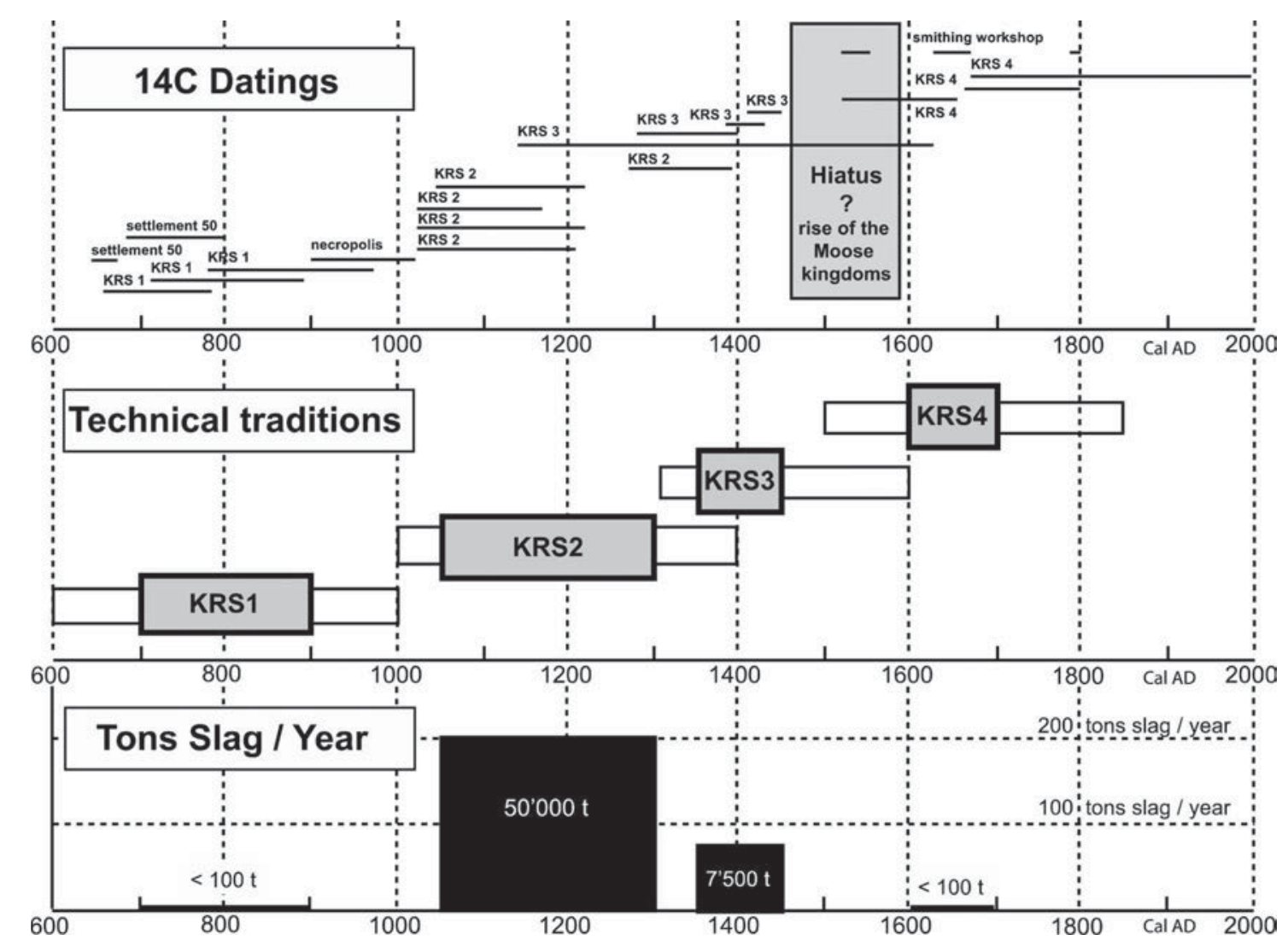

Figure 7. Chronological frame for the iron smelting complex of Korsimoro. Above: ${ }^{14} \mathrm{C}$ datings (Beta Analytic). Middle: Probable duration for the four technical traditions. Below: Estimates of the annual slag output (the iron output is $10-20 \%$ of the slag output).

\section{The chronologic frame of the iron production at Korsimoro}

Furnaces and other remains belonging to each of the various technical traditions were excavated in different parts of the site. All together, 19 samples from Korsimoro were dated by ${ }^{14} \mathrm{C}$. The raw data and the stratigraphic positions of the dated samples are presented in the reports [11, 12]. This number of datings is very high for an African iron working site. But on the other hand, the global time range extended for about 1000 years, so there are only two samples per century.

Combining topographic maps and leveling measurements, satellite images, and direct observations on the field, volumes of the metallurgical waste deposits have been estimated (Table 1). The mass of slag was then calculated, based on the measurements of the mass of slag in several test pits for each technical tradition. Systematic and more detailed presentations of the slag quantity estimates for each area are given in the second report on Korsimoro [12]. It is not simple to calculate the amount of iron produced by each technique. At Korsimoro, the pieces of iron ore discovered during the excavation are of medium quality. Based on the richest analyzed ore $\left(65 \% \mathrm{Fe}_{2} \mathrm{O}_{3}\right)$, the mass balance calculation highlights a very small iron production for KRS 2 and 3 but a negative result for KRS 4 [26]. It must be supposed that a

Table 1. Quantification of the smelting remains from Korsimoro. Zones 19 and 90 are badly damaged and no number can be provided. Zones 20 and 30 contain small amounts of smelting remains not related to the four main technical traditions: they are omitted in this table.

\begin{tabular}{|c|c|c|c|c|c|c|c|c|c|c|c|c|}
\hline \multirow[b]{2}{*}{ Zones } & \multicolumn{3}{|c|}{ KRS 1} & \multicolumn{3}{|c|}{ KRS 2} & \multicolumn{3}{|c|}{ KRS 3} & \multicolumn{3}{|c|}{ KRS 4} \\
\hline & $\begin{array}{l}\text { Number of } \\
\text { furnaces }\end{array}$ & $\begin{array}{c}\text { Number of } \\
\text { clusters }\end{array}$ & Tonnage & $\begin{array}{l}\text { Number of } \\
\text { furnaces }\end{array}$ & $\begin{array}{l}\text { Number of } \\
\text { slagscatters }\end{array}$ & Tonnage & $\begin{array}{c}\text { Number of } \\
\text { furnaces }\end{array}$ & $\begin{array}{c}\text { Number of } \\
\text { slagheaps }\end{array}$ & Tonnage & $\begin{array}{l}\text { Number of } \\
\text { furnaces }\end{array}$ & $\begin{array}{c}\text { Number of } \\
\text { clusters }\end{array}$ & Tonnage \\
\hline 10 & \multirow{2}{*}{\multicolumn{2}{|c|}{ Destroyed }} & & 50 & 3 & 1150 & 12 & 12 & 412 & & & \\
\hline 19 & & & & $x$ & $x$ & $x$ & & & & & & \\
\hline 20 & 2 & 1 & 0.1 & 152 & 27 & 22266 & 29 & 29 & 3829 & 395 & 9 & 16.9 \\
\hline 30 & 101 & 4 & 12.2 & 7 & 1 & 130 & 32 & 32 & 1048 & & & \\
\hline 40 & 200 & 2 & 20.0 & & 24 & 15393 & 3 & 3 & 153 & & & \\
\hline 50 & 345 & 3 & 35.0 & 30 & 1 & 1500 & 8 & 8 & 385 & 251 & 9 & 12.5 \\
\hline 60 & & & & & 2 & 2900 & 11 & 11 & 1310 & & & \\
\hline 70 & & & & 19 & 7 & 4593 & 18 & 18 & 390 & & & \\
\hline 80 & & & & & 5 & 730 & & & & & & \\
\hline 90 & \multicolumn{2}{|c|}{ Destroyed } & & & & & & & & $x$ & $x$ & $x$ \\
\hline 100 & 79 & 4 & 8.8 & 14 & 9 & 2260 & 2 & 2 & 85 & 183 & 8 & 14.4 \\
\hline 110 & & & & & 2 & 500 & 2 & 2 & 70 & & & \\
\hline total & 727 & 14 & 76.1 & 272 & 81 & 51422 & 117 & 117 & 7682 & 829 & 26 & 43.8 \\
\hline
\end{tabular}


better ore has been used. A theoretical calculation based on a better ore at $75 \% \mathrm{Fe}_{2} \mathrm{O}_{3}$ gives a result of $160-170 \mathrm{~g}$ of iron per $1000 \mathrm{~g}$ of slag for KRS 1, 2, and 3 and $90 \mathrm{~g}$ for KRS 4.

The four technical traditions follow each other through time (Fig. 7). Each technique corresponds to one period of activity.

Technique KRS 1 is the oldest one. The time range defined by ${ }^{14} \mathrm{C}$ goes from 600 to $1000 \mathrm{AD}$. The production was certainly active for at least 200 years between 700 and 900 AD. Technique KRS 2 follows: 1000 to $1400 \mathrm{AD}$ with a minimal duration of 250 years between 1050 and $1300 \mathrm{AD}$. On the basis of ${ }^{14} \mathrm{C}$, it is not possible to demonstrate a chronological continuity or a hiatus between KRS 1 and 2. The technical shift is strong with the replacement of single use furnaces by permanent structures reused for many smelts. A significant increase in the size of the furnace can be noted. There are major changes in the organization and size of the production. KRS 1 is based on campaigns of iron production at a small scale. It is probably a seasonal activity of a small group of people. During the KRS 2 phase, the production rose to a much higher level and the activity must have been intensive and probably permanent with a numerous specialized labor force.

Then, KRS 3 replaced KRS 2 in a short time lapse between 1300 and $1350 \mathrm{AD}$, with a radical change in the furnace design and operation. There is no chronological hiatus. The size of the production dropped, but remained significant. Iron production is still an intensive and permanent activity. The duration of phase KRS 3 seems to be short. It must have lasted at least 100 years, i.e., between 1350 and $1450 \mathrm{AD}$. The maximal ${ }^{14} \mathrm{C}$ range is longer (1300-1600 AD) but no feature is clearly dated after $1500 \mathrm{AD}$

Finally, the very small furnaces of KRS 4 are dated to the 17 th century (1600 to $1700 \mathrm{AD})$. It is probable that a short hiatus in iron production took place in the 16th century, but this is difficult to demonstrate with ${ }^{14} \mathrm{C}$ datings only. The KRS 4 furnaces are completely different from their predecessors. They are very small, non slag tapping, and operated with bellows. The organization went back to the campaign model and the size of the production decreased drastically. At Korsimoro very limited information is available on iron production after $1700 \mathrm{AD}$. At a few places, remains belonging to further technical tradition were identified, but no excavation was carried out. Following vague oral information, these remains are related to a more recent phase of production (19th century). As no eye-witness of the metallurgical activity is known, the production must have stopped before 1920 AD. During the 20th century, iron production was recorded in neighboring regions but not at Korsimoro [7].

The story told by the metallurgical remains of Korsimoro is a specific one and cannot be extrapolated from a larger geographical area without questioning. At Korsimoro, before $1000 \mathrm{AD}$, the production of iron was mastered, but the output remained at a small scale for several centuries. Iron must have been present in the material culture of the local populations but it was not used in large quantities. Later on, after 1000 $\mathrm{AD}$, there was a dramatic change. The production rose enormously, the technology changed, and the organization became much more intensive. At least a very significant fraction of the inhabitants of Korsimoro, if not all of them, was involved in the production of iron and the products must have supplied a large market or even entered a long distance trade network. This evolution seems to be rapid. From the technological point of view, KRS 2 can be seen as an evolution from KRS 1. The furnaces are larger and permanent but still based on induced draft and slag pits. From the economical point of view, the transformation is drastic, reflecting probably a general modification of the society. Much larger quantities of iron were in demand. This metal was used for agricultural tools, allowing a significant increase in the food production. A large segment of the population became specialized in iron working and the products are marketed at large scale. There is no doubt that this had been a significant societal transformation on regional scale.

In the 14th century, KRS 2 was replaced rapidly by the new technology KRS 3. At that time, a significant drop in the output took place, but the volume of the production was still clearly exceeding the local needs. The size of the specialized labor force must have decreased more or less in proportion, but remained important. From the technological point of view, the new technology is quite different, with the introduction of slag tapping. This can be seen as technological evolution, possibly in the direction of a more efficient process. The archaeometallurgical study does not confirm a marked increase of the iron yield, as the composition of the slag does not change. On the contrary, the change in technology is associated with other modifications. It is striking that the new furnaces were built with a different material: reused tuyère fragments are systematically incorporated in the shaft wall of KRS 3 furnaces. In the same way, the disposal of the waste is completely different. Those aspects have no or little effect on the efficiency of the process. They seem to be more related to cultural choices than to technical ones. The evidences point then in the direction of a technical change, resulting from a modification of the population. KRS 2 people had probably to leave Korsimoro and were replaced by a new cultural group bringing its own technology KRS 3 .

The oral history of the Mossi kingdoms mentions the presence of a previous population called Kibsi. They were present in the North before the arrival of the Nakombse conquerors from the 15th century onwards [2]. The Kibsi are in general considered as a part of the Dogon group. Recent research in the actual Dogon country around Bandiagara in Mali supports the idea that the Dogon, originally from Mandé, migrated in successive waves between the 13th and the 15th centuries [27]. Slag tapping technologies are identified in the Dogon country and the spatial organization of the "Ouin" tradition on the Bandiagara plateau is similar to KRS 3 [17]. On the other hand, there are significant differences between the "Ouin" tradition and KRS 3 (number of openings, building material, etc.) and more quite different technical traditions are recorded on the Dogon plateau, including several with slag pit furnaces. On this basis, one can only tentatively suggest that the KRS 3 furnaces can be attributed to Kibsi people, but the available data are not strong enough to demonstrate this hypothesis. Many other scenarios are possible and the actual knowledge about the period does not allow to be affirmative.

Recent research between Zitenga and Mané, $20 \mathrm{~km}$ to the West of Korsimoro, highlighted another technique (YNBS) 
that flourished during the same time span 1300-1450 AD, and no remains with the characteristic of KRS 3 were identified among 100 visited sites (fieldwork by E. Thiombiano-Ilboudo, [15]). This example highlights the complexity of the historical pattern of the iron industry.

At Korsimoro, the large-scale production ended within the 15 th century. What followed was a probable hiatus and a small-scale recovery after one century or so of abandonment. Once again the technological shift is abrupt. The KRS 4 tradition is completely the opposite of the previous KRS 3 regarding technical aspects, scale of production, and social organization. From the archaeometallurgical study, it even appears that the efficiency of the process decreased.

The hiatus between 1450 and 1550 is contemporary to the advance of the horse riding warriors known as Nakombse, entering progressively the territory of the White Volta basin from the South [3]. They organized new political entities, the Mossi kingdoms. The native populations were assimilated or forced out. The Kibse and their blacksmiths who tried to resist were forced to move in the direction of the Bandiagara cliff. The abandonment of the smelting activity at Korsimoro can be related to this episode, mentioned in the oral history.

It is also possible that 300 to 400 years of very intensive production exhausted the fuel resources. The wood shortage can be a good reason for the interruption of the production, but the archaeological data are not strong enough to prove it in this case.

It is not credible that the demand for iron dropped significantly with the development of the Mossi kingdoms. It is also not defendable that, in the 15th and 16th centuries, the iron supply imported by Europeans on the coast was large enough to fulfill the request as far inland as Burkina Faso [28, 29]. It is much more probable that other centers of production took over in neighboring regions. Later, during the 19th century, the province of the Yatenga, $100 \mathrm{~km}$ to the North-West of Korsimoro, was an important iron producing district. The description given by Captain Noiré in 1904 mentions 1500 furnaces in activity and an annual production of 539 tons of metal $[5,6]$.

\section{Conclusions and Perspectives}

Korsimoro is a complex iron smelting site, active for 1000 years, between 700 and $1700 \mathrm{AD}$, with four well-defined phases of production. After $1000 \mathrm{AD}$, for a period of about 500 years, it became a very important center of production with an output exceeding by far the local needs. The industry was intensive and requested a huge labor force. This period of massive production is well dated at Korsimoro, but what is known from other metal producing areas in Western Africa seems to confirm the development of iron production during the same time range. The increase of production makes sense only if the consumption grows in the same way. The consumption of iron mainly reflects the increasing use of soil digging metal tools for agriculture. Metal tools caused the increase of farmer productivity and the global production of food. The availability of food surplus is a major factor for economic development. At a very general level, this is a key factor to build up more complex and more structured societies. Iron plays an important role in this transformation and it makes sense to call this development the "Iron Age Revolution", as there is a significant change in the global technical system of the societies.

The rise of iron production is a fascinating aspect of the transformation of the West African societies. It makes sense to investigate it in detail to reconstruct the chronological and geographical frames of its advent and development. It is also possible, and even relatively easy, to investigate it, as the archaeological record in West Africa is quite good. In many places, the iron smelting remains are well preserved and accessible for study. Simple archaeological fieldwork provides data on technologies and quantities and sample for dating.

The iron smelting remains of Korsimoro are also exciting because they show evidences for abrupt changes in technology. The understanding of these events is a puzzling question. They can be the result of military or political situations or reflect economical processes like the promotion of a higher efficiency. Comparison between technical traditions allows to establish new links across long distances.

The archaeological remains related to iron smelting in Western Africa are a fantastic cultural heritage. They are also key information to understand the past history of the continent. At an even more general level, there is much to learn from those remains to understand the processes of technical invention and innovation.

\section{Acknowledgments}

The two fieldwork campaigns (2011 and 2012) were undertaken under the direction of Vincent Serneels together with $\mathrm{L}$. Simporé, L. Koté, E. Thiombiano-Ilboudo, and their students of the Département d'Histoire et d'Archéologie at the University of Ouagadougou (Burkina Faso). A group of the Département d'Archéologie (ISAD) at the University of Abidjan (Côte d'Ivoire) also participated in the fieldwork with H.T. Kiénon-Kaboré and S.K. Kouassi. M. Mauvilly, L. Kramer, A. El Kateb, P. Jobin, F. Donadini, and I. Katona-Serneels contributed to the supervision of the fieldwork and elaboration of the data. The Department of Geoscience at the University of Fribourg provided important support.

I thank the local authorities of the town of Korsimoro and the inhabitants for warm welcome and helpful support.

\section{Funding}

The joint project "Origine et développement de la métallurgie du fer au Burkina Faso et en Côte d'Ivoire" is funded by the Swiss-Liechtenstein Foundation for Archaeology (SLSA).

\section{References}

[1] Pageard, R. Une enquête historique en pays mossi. Journal de la Société des Africanistes 1965, 35 (1), 11-16.

[2] Izard, M. Le Yatenga précolonial - Un ancien royaume du Burkina, Edition Karthala: Paris, 1985; 164.

[3] Izard, M. Moogo - L'émergence d'un espace étatique ouest-africain au XVIe siècle, Edition Karthala: Paris, 2003; 394.

[4] Binger, L.G. Du Niger au Golfe de Guinée par le pays de Kong et le Mossi; Librairie Hachette, Paris, 1892; 2 vol., 513 pp. + 416 pp. 
[5] Noiré Monographie du cercle de Ouahigouya, Manuscript (Archives de la France d'outre-mer), 1904.

[6] Tauxier, L. Le noir du Yatenga, Mossis - Nioniossés - Samos Yarsés - Silmi-Mossis - Peuls, Emile Larose Libraire: Paris, France, 1917; 790 .

[7] Kiethéga, J.-B. La métallurgie lourde du fer au Burkina Faso - Une technologie à l'époque précoloniale, Edition Karthala: Paris, 2009; 500.

[8] Kiénon-Kaboré, H.T. La métallurgie ancienne du fer au Burkina Faso: province du Bulkiemdé, Editions L'Harmattan: Paris, $2003 ; 328$.

[9] Coulibaly, E. Savoirs et savoir-faire des anicens métallurgistes d'Afrique - Procédés et techniques de la sidérurgie directe dans le Bwamu (Burkina Faso et Mali), Editions Karthala: Paris, 2006; 422.

[10] Birba, N. La sidérurgie ancienne dans la province du Bam (Burkina Faso): approches archéologique, archéométrique et ethno historique, $\mathrm{PhD}$, Université Paris 1 Panthéon Sorbonne, 2016; 570 pp.

[11] Serneels, V.; Kiénon-Kaboré, H.T.; Koté, L.; Kouassi, S.K.; Ramseyer, D.; Simporé, L. Origine et développement de la métallurgie du fer au Burkina Faso et en Côte d'Ivoire. Premiers résultats sur le site sidérurgique de Korsimoro (Sanmatenga, Burkina Faso). Jahresberichtder Schweizerisch-Liechtensteinische Stiftung für Archäologische Forschungen im Ausland (SLSA) 2012, 23-54

[12] Serneels, V.; Donadini, F.; Kiénon-Kaboré, H.T.; Koté, L.; Kouassi, S.K.; Ramseyer, D.; Simporé, L. Origine et développement de la métallurgie du fer au Burkina Faso et en Côte d'Ivoire. Avancement des recherches en 2013 et quantification des vestiges de Korsimoro (Burkina Faso). Jahresbericht der Schweizerisch-Liechtensteinische Stiftung für Archäologische Forschungen im Ausland SLSA 2014, 65-112.

[13] Donadini, F.; Serneels, V.; Kapper, L.; El Kateb, A. Directional changes of the geomagnetic field in West Africa: Insights from the metallurgical site of Korsimoro. Earth and Planetary Science Letters 2015; 430:349-355. doi:10.1016/j.epsl.2015.08.030

[14] El Kateb, A. Etude archéométrique des déchets métallurgiques du fer à Korsimoro (Burkina Faso), Master thesis, Department of Geosciences, University of Fribourg, Switzerland, 2013; 144.

[15] Serneels, V.; Eichhorn, B.; Kiénon-Kaboré, H.T.; N'Zébo, L.; Ramseyer, D.; Thiombiano-Ilboudo, E.; Yéo, A. Origine et développement de la métallurgie du fer au Burkina Faso et en Côte d'Ivoire (5). Prospections et sondages dans la région de Yamane (Burkina Faso) et recherches à Siola 4000 (Côte d'Ivoire). Jahresbericht der Schweizerisch-Liechtensteinische Stiftung für Archäologische Forschungen im Ausland SLSA 2016, 67-102.

[16] Perret, S.; Serneels, V. Technological characterization and quantification of a large scale iron smelting site in Fiko, Mali. In Proceedings/Actes ISA2006, 36th International Symposium on Archaeometry ISA 2006, Quebec, Canada, May 2-6, 2006; Moreau, J.-F.; Auger, R.; Chabot, J.; Herzog, A. Cahiers d'Archéologie du CELAT 25, CELAT, université Laval, Quebec, 2009; 453-463.

[17] Robion-Brunner, C. Forgerons et sidérurgie en pays dogon, vers une histoire de la production du fer sur le plateau de Bandiagara (Mali) durant les empires précoloniaux, Journal of African Archaeology Monograph Series 3, Africa Magna Verlag, Frankfurt, 2010; 167.
[18] Robion-Brunner, C.; Serneels, V.; Perret, S. Variability in iron smelting practices: Confrontation of technical, cultural and economic criteria to explain the metallurgical diversity in the Dogon area (Mali). In The World of Iron ; Humphris, J., Rehren, Th. Eds.; Archetype Publications: London, 2013; 257-265.

[19] Echard, N. Noces de feu, $16 \mathrm{~mm}$. Comité du Film Ethnographiques (Musée de l'Homme), Paris, France, 1968; 32 minutes.

[20] Echard, N. Scories et symboles - Remarques sur la métallurgie hausa $\mathrm{du}$ fer au Niger. In Métallurgies africaines. Nouvelles contributions. Mémoires de la Société des Africanistes 9, Echard N. Ed.; Société des Africanistes, COPEDITH: Paris, 1983; 209-224.

[21] Serneels, V.; Kiénon-Kaboré, H.T.; Koté, L.; Kouassi, S.K.; Mauvilly, M.; Ramseyer, D.; Simporé, L. Origine et développement de la métallurgie du fer au Burkina Faso et en Côte d'Ivoire. Premiers résultats sur le site sidérurgique de Siola (Kaniasso, Denguélé, Côte d'Ivoire). Jahresbericht der Schweizerisch-Liechtensteinische Stiftung für Archäologische Forschungen im Ausland SLSA 2013, 113-144.

[22] Serneels, V.; Jobin, P.; Kiénon-Kaboré, H.T.; Koté, L.; Kouassi, S.K.; Ramseyer, D.; Thiombiano-Ilboudo, E.; Simporé, L. Origine et développement de la métallurgie du fer au Burkina Faso et en Côte d'Ivoire. Seconde campagne dans la région de Kaniasso (Folon, Côte d'Ivoire) et autres recherches. Jahresbericht der SchweizerischLiechtensteinische Stiftung für Archäologische Forschungen im Ausland SLSA 2015, 23-60.

[23] Robion Brunner, C.; Haour, A.; Coustures, M.-P.; Champion, L.; Béziat, D. Iron production in Northern Benin: Excavations at Kompa Moussékoubou. Journal of African Archaeology 2015; 13 (1), 39-57. doi:10.3213/2191-5784-10263

[24] Guillon, R.; Petit, C.; Rajot, J.-L.; Abdourhamane Touré, A.; Idé, O.A.; Garba, Z. Classification et chronologie de bas bourneaux de réduction du fer à usage unique au sud-ouest du Niger (Afrique de l'ouest). Journal of African Archaeology 2016, 14 (1), 55-82. doi:10.3213/2191-5784-10283

[25] Killick, D. Iron smelting technology in the Middle Senegal Valley, ca. 550 BCE-1500 CE. In The Search for Takrur: Archaeological Excavations and Reconnaissance along the Middle Senegal River Valley; McIntosh R.J., Keech McIntosh S., Bocoum H., Eds.,; Yale University Publications in Anthropology: New Haven; in press 2016.

[26] Eschenlohr, L.; Serneels, V. Les bas fourneaux mérovingiens de Boécourt-Les Boulies (JU/Suisse), Cahier d'Archéologie Jurassienne no 3, Office du Patrimoine Historique et Société Jurassienne d'Emulation, Porrentruy, Switzerland, 1991; 144.

[27] Gallay, A.; Huysecom, E.; Mayor, A. Archéologie, Histoire et traditions orales: trois clefs pour découvrir le passé dogon. In Die Kunst der Dogon, Catalogue d'exposition Museum Rietberg Zürich 1995; Homberger, L. Ed.: Museum Rietberg, Zürich, 1995; 13-43.

[28] Curtin, P.D. Economic change in precolonial Africa - senegambia in the Era of the Slave Trade, University of Wisconsin Press: Madison, 1975; 363.

[29] Evans, C. "Guinea rods" and "Voyage Iron": metals in the Atlantic slave trade, their European origin and African impacts, Paper presented at Economic History Society Annual Conference, Wolverhampton, Great Britain, March 27-29, 2015; 15. http:// www.ehs.org.uk/events/annual-conference-programme-2015.html 